\title{
NORTHERN REDBELLY SNAKE AT ANTLER
}

DALE HJERTAAS, 919 Cook Crescent, Regina, Saskatchewan. S4X 2L9

My unexpected reward for attending Thanksgiving dinner at Mom and Dad's was a modest range extension for the Northern Redbelly Snake (formerly Northern Red-bellied Snake). My uncle, Val Stuckey, described a small snake with a red belly which the Pioneer elevator agent at Antler had caught and was keeping in a jar.

On October 11, 1983 I telephoned the elevator agent, Mr. Donald Renet. He reported catching the snake on Tuesday, October 4, near the rail line beside his elevator. C.P. Rail were rebuilding the line at this time. Thus this secretive snake, which is most often found under rocks or logs, could have been disturbed by construction and so been found.

$\mathrm{Mr}$. Renet described the snake as 8-9 inches long, about pencil size in diameter, brown above, with a dark orange belly (Val Stuckey described it as orange-red). This fits the description of the Northern Redbelly Snake, Storeria occipitomaculata, which is the only Saskatchewan snake with a red belly. ${ }^{1} 2$ Identification thus appears certain even though the specimen was released where it was found on October 7 , and no photographs were taken.

The Northern Redbelly Snake has previously been reported in Saskatchewan in and near the eastern Qu'Appelle Valley at Crooked Lake, Grenfell, Hazel Cliffe, and Langenburg. Preston shows it extending across southern Manitoba except for the southwest corner, including the area adjacent to Antler. ${ }^{2}$ This specimen thus represents a modest southward range extension and Saskatchewan's first record outside the Qu'Appelle drainage.

1 COOK, FRANCIS R. 1966. A guide to the Amphibians and Reptiles of Saskatchewan. Saskatchewan Museum of Natural History, Regina. 40 pp.

2 PRESTON, WILLIAM B. 1982. The Amphibians and Reptiles of Manitoba. Manitoba Museum of Man and Nature, Winnipeg, Manitoba. 128 pp.

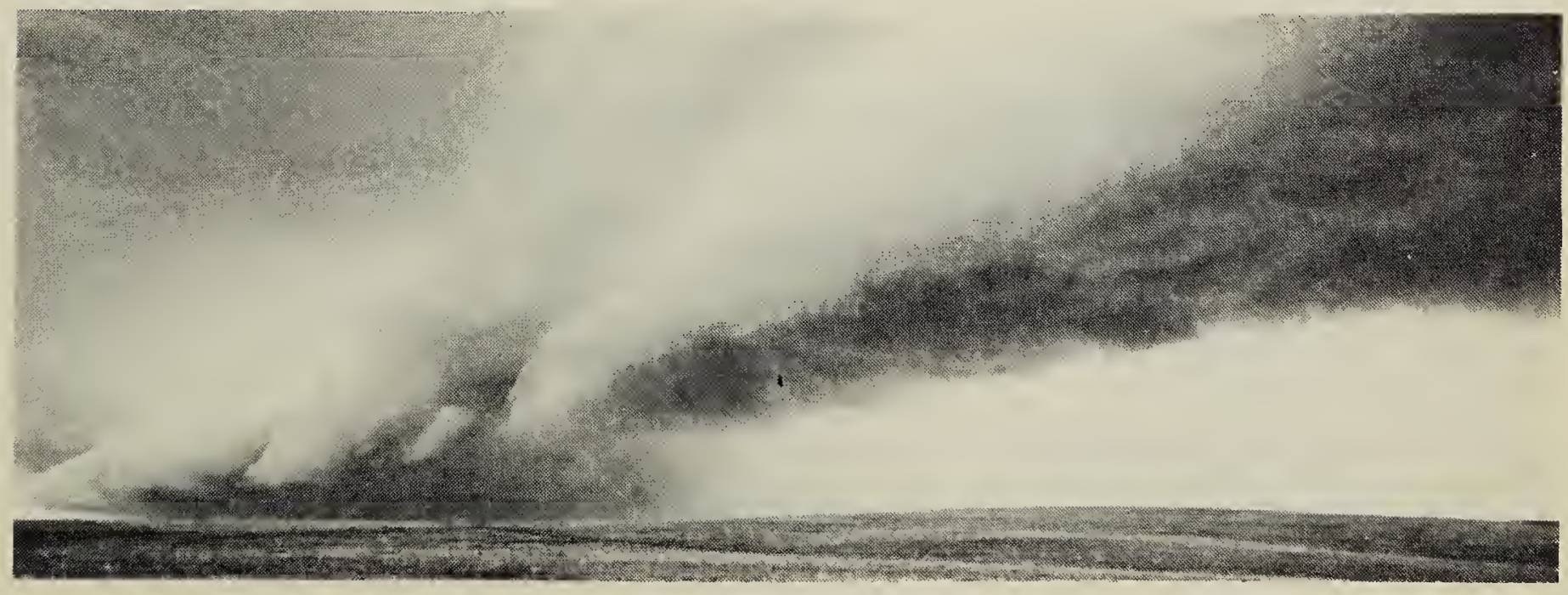

